\title{
The Special Issue 'Forced Migration and Refugeedom in the Modern Middle East' Towards Connected Histories of Refugeedom in the Middle
} East

\author{
Jordi Tejel \\ University of Neuchâtel, Switzerland \\ jordi.tejel@unine.ch \\ Ramazan Hakkı Öztan \\ University of Neuchâtel, Switzerland \\ ramazan.oztan@unine.ch
}

\begin{abstract}
This special issue approaches the study of refugees and forcibly displaced persons in the Middle East beyond the analytic bounds dictated by states, nations and regions. Each author is interested in showing connections, influences, and far-reaching consequences that cut across analytic boundaries. By challenging state-centred accounts and instead placing refugees, institutions, and states in a mutually interactive framework, each contributor frames refugees as the driving force behind various historical processes. By providing a range of case studies drawn from the Middle East, the volume also marks a step away from the Euro-centrism that so often defines the study of refugees and shows the centrality of the developments in Europe for the Middle East and the developments in the Middle East for Europe. We therefore propose the connected histories of refugeedom as the historiographical way forward in the study of refugees.
\end{abstract}

\section{Keywords}

refugees - forcibly displaced - Ottoman Empire - Middle East - historiography Refugee and Forced Migration Studies 
The Middle East's encounters with refugees date back to the late 1850 s when the Ottoman Empire was flooded by the influx of Muslim refugees fleeing the violence and warfare that ran havoc throughout the Caucasus. ${ }^{1}$ Thereafter, each successive cycle of warfare only repeated this pattern of displacement, as the Ottoman Empire not only continued to receive but also began to generate refugees of its own. By the end of the First World War, displacement had already become an urgent international problem with the surge of refugees that originated from the sites of collapsing empires, civil wars, and massacres. Against this backdrop the League of Nations - a new organisation in and of itself - responded by establishing a refugee regime by introducing standardised paperwork and procedures, complete with a range of relief programmes designed for the accommodation of the displaced.

By the early 1920s, the post-war settlement introduced a precise territorial order to the region with a new set of international boundaries. The introduction of sovereign territoriality was accompanied by the efforts of the emerging ruling elites in the region to re-define who belonged to the nation and thereby what determined the criteria for citizenship. These terms of inclusion, however, also specified the terms of exclusion, as some groups were defined out of state, leading to their categorisation as refugees and aliens. Both the League of Nations and local elites perceived refugeedom not only as an opportunity to minimise the prospects of ethno-religious conflict but also as a means of consolidating the nation-state. As such, creating refugees and welcoming them was a mutually constitutive process that reproduced discourses of governmentality and justified the modern territorial state, while redefining the limits of belonging. ${ }^{2}$

This special issue pursues a discussion about these themes around three clusters of research questions. On a theoretical level, it seeks to explore the relationship between modern notions of territorial sovereignty and refugeedom. How does the exclusion of certain groups as refugees determine the terms of national inclusion and thereby consolidate bounded communities?

1 This special issue was supported by the European Research Council (ERC) under the European Union's Horizon 2020 research and innovation programme Grant Agreement (No 725269). In addition, the Gerda Henkel Foundation through its Special Programme Islam, the Modern Nation State and Transnational Movements generously sponsored the conference 'Discourses on Refugees, Practices of Belonging: Refugee Regimes in the Making of the Middle East' held at the University of Neuchâtel in October 2018 where the six papers published in this special issue were presented.

2 Mark Mazower, No enchanted palace: The end of Empire and the ideological origins of the United Nations (Princeton 2009) 104-148; Laura Robson, States of separation: Transfer, partition, and the making of the modern Middle East (Oakland 2017). 
On a discursive level, the special issue aims at excavating the discourses surrounding the refugees in the interwar Middle East and showcases how refugee flows became a resource for the emerging territorial order in the interwar period. In what ways were the refugees a tool for state expansion, border-making processes, and population control? Finally, it seeks to unpack the making of refugee regimes across the Middle East. To what extent did the nineteenthcentury experiences of refugee settlement shape/influence the making of the refugee regimes in the later interwar period?

In the past two decades, historians have made important contributions to 'Refugee and Forced Migration Studies', a field which was once dominated by social science disciplines. ${ }^{3}$ This does not mean, however, that historians and history had been totally absent in the ongoing discussions before. As Jérôme Elie puts it, historians did work on refugees and forced migration, but they often situated their work within other historiographical fields, such as the history of the slave trade, the two world wars, genocide, the Cold War, humanitarian interventions and transnational history. ${ }^{4}$ The interwar era, for instance, saw a flurry of publications on the mass refugee movements triggered by the First World War. ${ }^{5}$ Scholars active in the immediate post-Second World War era were similarly prolific. ${ }^{6}$ While the refugee issue was at the centre of a growing literature, many historians prioritised institutional histories, or engaged with information on groups and individuals presented through the prism of institutional archives such as those of the League of Nations or the UNHCR. ${ }^{7}$ Furthermore,

3 Philip Marfleet, 'Refugees and history: Why we must address the past', Refugee Survey Quarterly 26:3 (2007) 137-147; Dawn Chatty and Philip Marfleet, 'Conceptual problems in forced migration', Refugee Survey Quarterly 32:2 (2013) 1-13; B. S. Chimni, "The birth of a "discipline”: From refugee to forced migration studies', Journal of Refugee Studies 22:1 (2009) 11-29.

4 Jérôme Elie, 'Histories of refugee and forced migration studies', in: Elena Fiddian Qasmiyeh et al. (eds), The Oxford handbook of refugee and forced migration studies (Oxford 2014) 23-35.

5 James L. Barton, Story of Near East Relief, 1915-1930 (New York 1930); L. W. Holborn, 'The League of Nations and the refugee problem', Annals of the American Academy of Political and Social Science 203 (1939) 124-135.

6 Eugene M. Kulischer, Europe on the move: War and population changes, 1927-47 (New York 1948); Malcolm Proudfoot, European refugees: 1939-52. A study in forced population movement (London 1956).

7 G. Woodbridge, UNRWA: The History of the United Nations Relief and Rehabilitation Administration, 3 vols. (New York 1950). 
despite their claims of universality, such historical scholarship was largely focused on Western European issues, ${ }^{8}$ with only few notable exceptions. ${ }^{9}$

Similar trends characterised the scholarship that emerged in the early 1990s, whereby the major scholarly theme continued to be the exploration of European policies and popular attitudes to refugees in the 1930s, especially towards the Jews from Germany. ${ }^{10}$ These studies certainly helped scholars reconsider the roles played by international organisations, such as Claudena Skran's study of the emergence of the refugee regime in interwar Europe, and Gil Loescher's history of UNHCR. ${ }^{11}$ While these influential authors had detailed the development of institutions and analysed case studies about the historical response to refugee protection needs, their narratives were 'at times anecdotal, selective or lack[ed] a broader historical contextualization beyond the issue of refugees.' ${ }^{12}$

Peter Gatrell, in a very provocative article, raises additional criticisms of the existing literature on refugees and mass population displacement. ${ }^{13}$ On the one hand, the traditional state-centred approaches adopted by historians inevitably came at the expense of studying non-state actors, such as refugees and forced migrants. Even when historians acknowledged their historical significance, they often did so by framing them as the mere 'by-products' of larger state-centred processes of imperial cataclysms and nation formation. Despite the huge scale of mass displacement across the world, such historiographical trends thus continue to persist, as refugees are still depicted at best as victims of wars or revolutions, but rarely as agents of change. ${ }^{14}$ On the other hand, Gatrell argues that although numerous examples show that refugeedom may indeed become a long-term condition (e.g. Palestinians, Vietnamese in Hong Kong, and Saharawi refugee camps) and the refugee crises are more frequent than episodic, historians often shy away - certainly more so than social scientists - from exploring the systemic factors behind forced migrations and seeing refugees as central to the making of history. To put it differently, 'refugee

Michael R. Marrus, The unwanted: European refugees from the First World War through the Cold War (Oxford 1985); Rob Moore, Refugees from Nazi Germany in The Netherlands 1933-1940 (Dordrecht 1986).

9 Benny Morris, The birth of the Palestinian refugee problem, 1947-49 (Cambridge 1989).

10 Vicki Carron, Uneasy asylum: France and the Jewish refugee crisis, 1933-42 (Stanford 1999).

11 Claudena M. Skran, Refugees in Inter-War Europe: The emergence of a regime (Oxford 1995); Gil Loescher, The UNHCR and world politics: A perilous path (Oxford 2001).

12 J. Olaf Kleist, 'The history of refugee protection: Conceptual and methodological challenges', Journal of Refugee Studies 30:2 (2017) 161-169, 161.

13 Peter Gatrell, 'Refugees-What's wrong with history?', Journal of Refugee Studies 30:2 (2017) 170-189.

14 Peter Gatrell, The making of the modern refugee (Oxford 2013). 
history cannot just be about refugees', for the history of refugees and displaced populations is 'bound up with a broader set of relations and practices. ${ }^{15}$

In line with Gatrell's observations, historical scholarship has been undergoing an important transformation since the early 200os, as three parallel dynamics gradually paved the way towards a greater engagement of historians with the field of 'Refugee and Forced Migration Studies'. First, the influence of sub-disciplines of modern historical studies, such as transnational and global history, began to play central roles in revising the approaches of historians towards forced migrations. For one, growing dissatisfaction with the existing literature informed by 'methodological nationalism' soon led historians to go beyond simple national histories towards a better appreciation of connections and circulations of people, goods, and ideas. ${ }^{16}$

Scholars have accordingly begun to underline the need for a global history of displacement and relief programmes over time. ${ }^{17}$ In doing so, they have established comparisons between different geographical areas, identifying both the continuities and discontinuities in a wide range of related topics such as practices, discourses and the condition of being refugees; that is, refugeedom. To date, perhaps historians of humanitarianism have been the most enthusiastic practitioners of such a global approach to the study of refugees. As Emily Baughan puts it, many studies in the history of humanitarianism and international institutions pitched themselves as examinations of the antecedents of our present globalised world. ${ }^{18}$ The 'global turn' among historians of humanitarianism was thus all the more natural.

The second crucial historiographical shift in the study of refugees since the early 200os was rooted in the broader push to recover the agencies of historical actors, an effort long in the making since the postcolonial turn. Like many

15 Gatrell, 'Refugees-What's wrong with history?', 178.

16 Christopher Bayly, The birth of the modern world, 1780-1914 (Malden, MA 2004); Ilham Khuri-Makdisi, The Eastern Mediterranean and the making of global radicalism, 1860-1914 (Berkeley 2010); Jürgen Osterhammel, The transformation of the world: A global history of the nineteenth century (Princeton, NJ 2014); Valeska Huber, Channelling mobilities: Migration and globalisation in the Suez Canal Region and beyond, 1869-1914 (Cambridge 2013); Ramazan Hakkı Öztan, 'Tools of revolution: Global military surplus, arms dealers, and smugglers in the Late Ottoman Balkans, 1878-1908', Past \& Present 237 (2017) 167-195; Houri Berberian, Armenians and the connected revolutions in the Russian, Iranian, and Ottoman Worlds (Oakland 2019).

17 Pamela Ballinger, 'Entangled or "extruded" histories? Displacement, national refugees, and repatriation after the Second World War', Journal of Refugee Studies 25:3 (2012) 366-386; Gatrell, The making of the modern refugee (Oxford 2013).

18 Matthew Hilton, Emily Baughan, Eleanor Davey, Bronwen Everill, Kevin O'Sullivan, Tehila Sasson, 'History and humanitarianism: A conversation', Past and Present 241:1 (2018) e1-e38. 
practitioners in other fields, historians engaged in 'Refugee and Forced Migration Studies' aimed at highlighting the agency of the 'subaltern', whether they constituted classes of women, migrants, and minorities, or that of refugees. By doing so, they started putting refugees at the centre rather than the margins of historical enquiry. Historians did not, however, need to re-invent the wheel; they could draw from well-established subfields of historical studies such as cultural and social history, and gender studies to observe the symbolic and discursive systems as well as the material objects that give meaning to refugeedom. ${ }^{19}$ Accordingly, refugees increasingly began to be seen as agents and subjects of history in their own right, with a historical capacity that went well beyond the passivity of victimhood too often ascribed to them. ${ }^{20}$

Finally, in conjunction with the broader push to move history and social science away from Euro-centrism, case studies focusing on the non-Western refugee crises started populating the field from the early 2000 onwards. ${ }^{21}$ It was only a matter of time before historians turned their attention to the Middle East - a region shaped over the past two centuries by refugees and forced migrations. Indeed, the modern Middle East has been both the source of and host to some of the largest forcibly displaced populations in the world. By 2017, for example, more than 60 per cent of the world's 21.3 million refugees as well as 30 per cent of the world's 38 million internally displaced persons were found in the Middle East. ${ }^{22}$ In addition, the region witnessed some of the most important episodes of forced migration throughout the first half of the twentieth century; namely the Armenian genocide in 1915-1916 and the expulsion of Palestinians from their homeland in 1948 and in 1967 , both contributing to the 'making of the modern refugee..23 And yet, by 2010, Dawn Chatty still lamented the lack of historical works devoted to issues of forced migration in the Middle East, despite the prominence of refugees in the making of the regional sociopolitical and economic order. ${ }^{24}$

19 M. Schrover et al. (eds), Illegal migration and gender in a global and historical perspective (Amsterdam 2008).

20 For an example that aims to recover refugee voices, see the historical project launched at the University of Manchester and led by Prof. Peter Gatrell, titled Reckoning with Refugeedom, 1919-1975 Refugee voices in modern history: https://reckoningwithrefugeedom.wordpress.com/.

21 Peter Gatrell, A whole empire walking: Refugees in Russia during World War One (Bloomington 1999); Catherine Gousseff, L'exil russe 1920-39. La fabrique du réfugié apatride (Paris 2008).

22 Dawn Chatty, 'Special issue introduction', International Journal of Middle East Studies 49 (2017) $577-582,577$.

23 Gatrell, The making of the modern refugee.

24 Dawn Chatty, Displacement and dispossession in the Modern Middle East (Cambridge 2010) 10. 
The state of the field is radically different today from what Dawn Chatty observed ten years ago, as the refugee crises in the Middle East - both old and new - continue to be the subjects of an important number of monographs, edited volumes and special journal issues. The late Ottoman era is by and large the period that has received the most attention, and it did so for two reasons. On the one hand, the Ottoman records are easier to access compared to those that relate to the more recent episodes of forced migration in the Middle East. On the other hand, the Ottoman Empire witnessed some of the most important chapters of forced displacement in history as a result of Ottoman territorial losses that began in the early nineteenth century. In particular, Russian expansionism into the Caucasus, Crimea, and the Balkans led to the forced migrations of around five million Muslims and their resettlement in the Ottoman domains, which present a greater range of case studies to the specialist willing to explore them. ${ }^{25}$

The traditional historiography on the subject was spearheaded by an older generation of historians who, with a proven track record in demographic history, had sought to remedy an earlier scholarship which eagerly identified Ottoman Muslims as the perpetrators of violence, but rarely as its victims. ${ }^{26}$ Building upon this literature was an emerging corpus of works that began to move into more analytically complex directions. In terms of refugees and violence, an increasing number of works have begun to challenge conceptual dichotomies such as 'victim'/'perpetrator' or 'state'/'civilians' that very often contribute to obscure the political, social and economic dynamics that may lead to the episodes of displacement and forced migration. According to this new strand of scholarship, local populations could be at times actors and at times subjects of violence. ${ }^{27}$ While states were indeed responsible for mass violence, local armed bands made up of former and recent refugees working at times independently and at times in conjunction with the state

25 Reşat Kasaba, A moveable Empire: Ottoman nomads, migrants and refugees (Seattle 2009) 108-139.

26 Important examples include Kemal H. Karpat, Ottoman population 1830-1914: Demographic and social characteristics (Madison 1985); Justin McCarthy, Death and exile: The ethnic cleansing of Ottoman Muslims, 1821-1922 (Princeton 1996).

27 Michael A. Reynolds, Shattering empires: The clash and collapse of the Ottoman and Russian Empires, 1908-18 (New York 2011); Omer Bartov and Eric D. Weitz (eds), Shatterzone of Empires: Coexistence and violence in the German, Habsburg, Russian, and Ottoman borderlands (Bloomington 2013). 
authorities - could turn into perpetrators of violence as well. ${ }^{28}$ Accordingly, scholars not only highlighted how refugees became an important factor for revolutionary movements (e.g. the Macedonian revolutionaries or the Young Turks), but also the ways in which the refugee experience could have a decisive impact on a leadership level, as it was the case in the Turkish Republic. ${ }^{29}$

Therefore, while the twentieth century was the century of the refugee in Europe, it was the nineteenth century for the Ottomans. ${ }^{30}$ The growing realisation, since the early 2000s, of this fact, coupled with an increasing desire to integrate the late Ottoman history into the European mainstream, pushed a new generation of historians to highlight the centrality of the late Ottoman experience to the making of modern refugeedom in general, and that of the Middle East in particular. For historians, this task required thinking anew the history of the Ottoman institutional responses in resettling Muslim refugees. Starting with Cuthell's study of the Muhacirin Komisyonu (Migrants Commission) - an Ottoman institution created in 1860 to deal with the incoming waves of Tatar refugees, an emerging corpus began to examine the institutional evolution of Ottoman policies, with an emphasis on the practices of refugee aid, programmes of resettlement, and the corresponding transformation of legal categorisations. ${ }^{31}$ These institutional responses were not episodic, but rather formed an evolving bureaucratic script of Ottoman governance that eventually informed the imperial practices of demographic engineering, as well as the processes of internal colonisation across the empire. ${ }^{32}$

28 Ryan Gingeras, Sorrowful shores: Violence, ethnicity, and the end of the Ottoman Empire, 1912-23 (Oxford 2009).

29 Erik J. Zürcher, "The Balkan Wars and the refugee leadership of the Early Turkish Republic', in: Hakan Yavuz and Isa Blumi (eds), War and nationalism: The Balkan Wars, 1912-13, and their sociopolitical implications (Salt Lake City 2013) 665-678.

3o Jared Manasek, Empire displaced: Ottoman-Habsburg forced migration and the Near Eastern Crisis, 1875-78, (Thesis Columbia University, New York 2013) 33.

31 David Cuthell, The Muhacirin Komisyonu: An agent in the transformation of Ottoman Anatolia, 1860-66, (Thesis Columbia University, New York 2005); James H. Meyer, 'Immigration, return, and the politics of citizenship: Russian Muslims in the Ottoman Empire, 1860-1914', International Journal of Middle East Studies 39 (2007) 15-32; Başak Kale, 'Transforming an Empire: The Ottoman Empire's immigration and settlement policies in the nineteenth and early twentieth centuries', Middle Eastern Studies 50:2 (2014) 252-271; Mustafa Tanriverdi, 'The Treaty of Berlin and the tragedy of the settlers from the Three Cities', in: Hakan Yavuz and Peter Snluglett (eds), War and diplomacy: Russo-Turkish War of 1877-78 and the Treaty of Berlin (Salt Lake City 2011) 449-478; Ella Fratantuono, 'State fears and immigrant tiers: Historical analysis as a method in evaluating migration categories', Middle East Journal of Refugee Studies 2:1 (2017) 97-115.

32 Nesim Şeker, 'Forced population movements in the Ottoman Empire and the Early Turkish Republic: An attempt at reassessment through demographic engineering', European 
This latter emphasis on internal colonisation was in line with the broader departure in Ottoman historiography from the histories of the centre towards the provinces of the empire. A range of micro-studies of refugee settlement emerged by building upon, but in many ways going well beyond, the crucial precursors in the literature, such as Karpat's study of Mecidiye. ${ }^{33}$ This emerging strand of scholarship, with its particular focus on the refugee settlements and sedentarisation of nomads, began to explore the ensuing land conflicts, changing property relations, and expansion of the networks of capital, locating through them the agencies of the newly settled refugees and nomads in challenging and transforming the vision of the Ottoman state to colonise the 'empty' lands from the corners of Western Anatolia to Syria and Transjordan. ${ }^{34}$ Locating refugee agency in transforming the Ottoman settlement practices also led scholars to question the analytic utility of the otherwise bureaucratic category of 'refugee' itself, calling for a shift of emphasis on human mobility and itinerancy instead ${ }^{35}$ - a plea shared by historians of mobility elsewhere. ${ }^{36}$

Settling refugees and providing shelter for them in its domains was only part of the Ottoman story, however. After all, the empire also generated refugees. The burgeoning of genocide scholarship since the mid-199os provided incentives and comparative possibilities to rethink the forced displacements of Ottoman Christians since the late nineteenth century. The scholarship that addressed the Ottoman policies from assimilation to demographic engineering accordingly grew in scope and became more nuanced over the years; and so did the historiography focusing on the genocidal policies of the Young Turks. ${ }^{37}$

Journal of Turkish Studies 16 (2013) URL: http://journals.openedition.org/ejts/4396; Fuat Dündar, 'How migration institutions "think"? The Ottoman-Turkish case', Anatoli 9 (2018) 165-186; Ella Fratantuono, 'Producing Ottomans: Internal colonization and social engineering in Ottoman immigrant settlement', Journal of Genocide Research 21:1 (2019) 1-24.

Mecidiye was a town established according to a central plan by the Ottoman authorities in 1856 to accommodate the incoming Crimean Tatar refugees. Kemal Karpat, 'Ottoman urbanism: The Crimean emigration to Dobruca and the founding of Mecidiye, $1856-78$ ', International Journal of Turkish Studies 3:1 (1984-85) 1-27.

34 Yücel Terzibaşoğlu, Landlords, nomads, and refugees: Struggles over land and population movements in North-Western Anatolia, 1877-1914 (Thesis University of London, London 2003); Nora Elizabeth Barakat, An empty land? Nomads and property administration in Hamidian Syria (Thesis University of California, Berkeley 2015); Vladimir HamedTroyansky, 'Circassian refugees and the making of Amman, 1878-1914', International Journal of Middle East Studies 49 (2017) 605-623.

35 Isa Blumi, Ottoman refugees, 1878-39: Migration in a post-imperial world (London 2013).

36 Valeska Huber, Channeling mobilities; Darshan Vigneswaran and Joel Quirk (eds), Mobility makes states: Migration and power in Africa (Philadelphia 2015).

37 Some representative publications include: Nesim Şeker, 'Demographic engineering in the late Ottoman empire and the Armenians', Middle Eastern Studies 43:3 (May 2007) 461-474; 
Because this vast scholarship engaged in debates of their own within the late Ottoman historiography, however, refugees were analytically reduced to mere historical outcomes, with voices and agencies often forgotten. ${ }^{38}$ It was this lacuna that recently spurred the emergence of a scholarship that started examining critically the entangled nexus of colonial paternalism, refugee agencies, and international humanitarianism in the interwar Middle East.

While historically there is a strong relationship between the emergence of the nation state and the generation of large-scale refugee movements in the modern Middle East, we know very little about how the arrival and settlement of refugees drove processes of state formation and shaped the conceptions of new territories. Benjamin T. White, for instance, has recently shown how the arrival of Armenian and Kurdish refugees into the French mandate of Syria triggered nation-wide debates by raising the stakes of the necessity to define Syria in terms of both geography and national identity. ${ }^{39}$ Such episodes of forced displacements that characterised the post-war state formation in the Middle East also led a group of scholars to develop critical readings on humanitarianism in the region. This emerging scholarship not only underlined the failures and the long-term legacies of humanitarian conduct for the making of the modern refugee regime, ${ }^{40}$ but also the fundamental 'racialised logic' that ironically drove the politics of liberal humanism amidst burgeoning postwar discourses of peace. ${ }^{41}$

Building upon the long nineteenth-century tradition of humanitarian intervention, the post-wwi practices and discourses of humanitarianism, albeit with a less colonial and missionary outlook, still shared the same civilisational hierarchies, drawing to the Middle East a range of non-state actors and organisations

Fuat Dündar, Modern Türkiye'nin Şifresi: Itttihat ve Terakkinin Etnisite Mühendisliği, 1913-18 (İstanbul 2008); Uğur Ümit Üngör, The making of modern Turkey: Nation and sate in Eastern Anatolia, 1913-50 (Oxford 2011); Taner Akçam, The Young Turks' crime against humanity: The Armenian Genocide and ethnic cleansing in the Ottoman Empire (Princeton 2012).

38 Some notable exceptions include Jo Laycock, Imagining Armenia: Orientalism, ambiguity and intervention (Manchester, 2009); Yael Schacher, 'Refugees and restrictionism. Armenian women immigrants to the USA in the post-World War I era', in: M. Schrover and D. Moloney (eds), Gender, migration and categorisation: Making distinctions between migrants in Western Countries 1945-2010 (Amsterdam 2013) 55-74.

39 Benjamin Thomas White, 'Refugees and the definition of Syria, 1920-1939', Past \& Present 235 (2017) 141-178.

40 Keith D. Watenpaugh, Bread from stones: The Middle East and the making of modern humanitarianism (Oakland 2015).

41 Aslı Iğsız, Humanism in ruins: Entangled legacies of the Greek-Turkish Population Exchange (Stanford 2018). 
with humanitarian agendas driven by a quasi-colonial mind-set. ${ }^{42}$ As humanitarian conduct continued to be part of the ideological underpinning that legitimised, if not facilitated, the mandatory rule in the Middle East, the British and French policies of separation and ethnic removal targeted the region's refugee communities, such as Armenians, Jews and Assyrians, as a way of consolidating their own colonial authority. ${ }^{43}$ Yet, such attempts to institute new regimes of mobility through the introduction of novel territorial controls and legal categorisations were both facilitated and frustrated by the agencies of refugees and immigrants themselves, by way of testing the limits and taking the opportunities provided by the mandatory framework. ${ }^{44}$ Therefore, historians have increasingly framed refugees as not only crucial to the post-wwi processes of nation-formation, but also constitutive of the evolving practices and discourses of humanitarianism accompanying the mandatory rule in the Middle East.

\section{3}

\section{In this Issue}

The collection of articles in this special issue builds upon this rich diversification of methodologies, analytic approaches and case studies in the study of refugees and forced displacement that we have witnessed for the past two decades or so. The recent humanitarian crises across the Mediterranean have certainly given further critical momentum to such studies of forced displacement, which often translated into a growing number of international workshops and conferences organised in the last few years. This special issue features select contributions from one such workshop held in October 2018 at the University of Neuchâtel (Switzerland) within the framework of an ERC project. Why a special issue on refugees and forced migration in the Middle East in the interwar era?

There are at least three inter-related reasons. First, as some practitioners of global history admit, case studies are essential to unpack the patterns of global development and illustrate the links between the local and the global. With a complex range of case studies, the interwar Middle East offers opportunities to test the validity of some of these global turning points and highlight new

42 Davide Rodogno, 'Non-state actors' humanitarian operations in the aftermath of the First World War: The case of the Near East Relief', in: Fabian Klose (ed), The emergence of humanitarian intervention: Ideas and practice from the nineteenth century to the present (Cambridge 2015) 185-207.

43 Robson, States of separation.

44 Lauren Banko, 'Refugees, displaced migrants, and territorialization in Interwar Palestine', Mashriq \& Mahjar 5:2 (2018) 19-48. 
avenues of research. Second, further study of the Middle East could help redress the Eurocentric bias that is still dominant in the field. While the postWWII European refugee crises are readily acknowledged to have shaped the terms and conditions of the international refugee regime, a less Eurocentric perspective may allow us to trace the roots of some of these policies back to the interwar years and earlier practices of refugee settlement. Finally, the Middle East challenges the liberal framing of the refugee crises to be 'transitional' experiences. Most prominently, the Armenian and Palestinian episodes illustrate how protracted political conflicts and forced migrations could very well create 'permanent' refugees. This special issue accordingly highlights the necessity to treat the Middle East on the same analytic field as that of the West, while calling for connected histories of refugees and forced displacement that seek to recover the ways in which refugeedom was interlocked with on-going discussions on national sovereignty, citizenship, interwar colonialism, and humanitarian work.

The first contribution is from Davide Rodogno who charts the coming of humanitarian aid to Palestine in the immediate aftermath of the First World War, with a focus on the American Red Cross (ARC), a non-state actor. Warning against the hagiographic accounts of humanitarianism, ${ }^{45}$ Rodogno provides a nuanced history of the philanthropic work on the ground, highlighting in particular the local exigencies and native contributions to broader relief operations. He notes, for example, the significance of the work carried out by a range of philanthropic organisations that had existed since the Ottoman times, and highlights the paradoxical role played by the British military in humanitarian operations. In describing the ARC mission to Palestine, Rodogno shows how the institution - in addition to recruiting individuals with more secular backgrounds - largely tapped into former missionary networks, a finding that highlights the continuities and ruptures in humanitarian practice from the nineteenth century to the interwar era. As he convincingly illustrates, however, the idealist discourses and practices of this diverse humanitarian body were actually 'filtered, transformed, and realised through local institutions, politics, and relationships'. The members of the ARC mission, as Rodogno points out, saw their relief work as a model that could actually perpetuate the work of the organisation in Palestine - a point that illustrates well how refugees were crucial for legitimising the existence of non-state organisations such as the ARC.

Next is the contribution by Victoria Abrahamyan who focuses on one such community of refugees - namely the Armenians - examining the historical

45 For instance, see Stanley E. Kerr, The lions of Marash: Personal experiences with American Near East Relief, 1919-1922 (Albany 1973). 
processes that their arrival triggered in French Syria. Building upon the existing arguments in the literature that highlight the significance of refugees in defining their host societies, Abrahamyan reconstructs the evolving discourses of the Armenian refugees in response to a burgeoning Arab nationalism in Syria and vis-à-vis an increasingly aggressive French policy of minority protection that both justified and facilitated the mandatory rule. Pairing the refugee language sources - namely the ones in Armenian - with those in Arabic, she illustrates the formation of Armenian identity in Syria by focusing on three key contentious episodes which brought the Armenian refugees into a nationwide debate on the future identity of Syria: the debates on citizenship and voting rights, in 1924-1925 and 1928; the politics of the Syrian Revolt in 1925; and the renewed discussions on the status of Armenian refugees in Syria, precipitated by the influx of Armenian refugees in 1929-1930. By tracing each of these episodes, Abrahamyan shows how the Armenian newspapers locked horns with the Syrian Arab press, and the various responses by the Armenian church and secular political parties towards the broader mandatory politics of minorities. As Abrahamyan crucially points out, the reactions of Syrian nationalists against Armenian refugees were driven in part by fears of Syria sharing a destiny similar to Palestine, where the majority was gradually dislodged by the politics of a minority favoured by the British.

This is exactly where Laura Robson picks up the debate, and she argues against the existing tendencies in the historiography to isolate Palestinian statelessness as a peculiar condition borne out of the local exigencies after 1948. Informed by a growing body of literature that highlights the connectedness of the interwar debates on citizenship, refugeedom and sovereignty, Robson seeks to reconstruct the discursive history of Palestinian statelessness as a constitutive background that 'created a global willingness to accept the physical outcomes of the eventual war' in 1948. Framing the Palestinians of the interwar era as 'proto-refugees,' Robson carefully charts the development of Palestinian statelessness as rooted in the discursive parameters of both the League of Nations as well as in the policies led by the British mandatory authorities. The League's responses to Palestinian claims, for example, was informed by the legal and civilisational language developed vis-à-vis similar claims made by the minorities in Eastern Europe and the Balkans. In an important intervention, Robson puts forth how refugeedom, minority regimes and statelessness in fact constituted the very raison d'être of post-war mechanisms of international authority, such as the League of Nations and the United Nations - two institutions that repeatedly failed to consider any alternative claim to nationhood.

Similarly highlighting the connectedness of the developments in the Middle East and Europe, Ramazan Hakkı Öztan provides a critical re-reading of 
Turkey's Settlement Law of 1934, placing it within the context of rising interstate tensions in the Balkans. The existing scholarship rightly pointed to the law's utility in Turkish nation-formation in general and the development of demographic engineering against the Kurds in particular. Even though this literature illustrated continuities in demographic policies from the Young Turks to the Kemalists, Öztan points to the problems embedded in such top-down analytic trajectories that were often borne out of methodological nationalism. By raising the question of the timing of the Settlement Law, he instead examines the crucial context of interstate tensions across Eastern Europe throughout the early 1930s, and argues that the making of the Settlement Law cannot be treated separately from this broader European context of a crumbling Versailles order. His analysis sees the collapse of the minorities treaties in Europe as a crucial development that quickly paved the way for the rivalling Balkan states, including Turkey, to pursue a range of demographic policies to pre-empt territorial revisionism across the region. The increasing interstate tensions, Öztan concludes, not only provided the necessary push and pull factors for forced migration or population transfers in the Balkans, but also defined the renewed urgency with which Ankara came to implement the settlement of Balkan Muslims across its territories.

Chris Gratien and Emily Pope-Obeda's contribution in turn shows how such interstate agreements aiming at ethno-religious homogenisation could at times have far-reaching consequences even across the Atlantic. In line with the recent diasporic turn in the late Ottoman studies, ${ }^{46}$ they examine how the Turkish-Greek population exchange of 1923 conditioned deportation practices in the United States throughout the 1930s in what they term as 'the Second Exchange'. Their focus is particularly on the period after the signature of the Ankara Convention which pronounced the Orthodox Greeks still living in Turkey and Muslims in Greece as of 1930 as exempt from the population exchange. In doing so, however, the Convention left all Muslims who lived elsewhere other than in Turkey and Greece still subject to population exchange. Gratien and Pope-Obeda show how such legal frameworks played into the hands of the immigration authorities in the USA, where a range of measures were already in

46 Andrew Arsan, John Karam and Akram Khater, 'On forgotten shores: Migration in Middle East Studies and the Middle East in migration', Mashriq \& Mahjar 1:1 (2013) 1-7; Andrew Arsan, Interlopers of Empire: The Lebanese diaspora in colonial French West Africa (New York 2013); Zeinab Emad Abrahim, Race across borders: Race and transnationalism in the First Syrian-American Community, 1890-1930 (Thesis University of Maryland, College Park 2013); Nadim Bawalsa, Palestinian migrants and the birth of a Diaspora in Latin America, 1860-1940, (Thesis New York University, New York 2017); Stacy D., Fahrenthold, Between the Ottomans and the Entente: the First World War in the Syrian and Lebanese Diaspora, 1908-1925 (New York 2019). 
the making to limit the number of immigrants, such as the introduction of country-specific immigration quotas in 1924. By tracing the individual cases gleaned from the archives, they not only illustrate the far-reaching legal consequences of the population exchange in the US, but also showcase the legal agencies of the Greek and Turkish authorities to pursue their own ethno-religious agendas in negotiating with their American counterparts.

In the final contribution, Ayşenur Korkmaz zooms in on the forcibly displaced persons and explores how they have come to terms with the experience of dispossession and removal from an ancestral homeland. She does so through a case study on the former Ottoman Armenians who were settled in the Turkish-Soviet borderlands after the Armenian Genocide in 1915. By examining the notion of ergir, the Armenian for homeland, Korkmaz traces the shifting meanings of the term in changing historical contexts from the 1920 so 196os, seeking to identify the spatial imaginings of Armenian refugees whose perspectives of their homeland were gradually defined as much by nostalgia for the past as the imperatives of belonging to a novel milieu. Korkmaz categorises the construction of ergir into three distinct periods, and analyses first the ways in which the remembrance of ergir was mixed with dominant themes of 'return to home' throughout the early Soviet years. She then focuses on the Stalinist regime under which the articulations of ergir were repressed systematically as it was seen as an anti-Soviet attitude borne out of bourgeoisie patriotism. The post-Stalin years accordingly witnessed the revival of literary and popular representations of ergir which had thus far remained silenced. In tracing the shifting trajectories of Armenian imaginations of homeland, Korkmaz provides a longitudinal contribution that utilises ethnographic fieldwork and oral interviews conducted with the descendants of Armenian refugees, with which she pairs the analyses of literature and other works of popular culture.

Taken as a whole, this special issue delivers an example of historical scholarship that approaches the study of refugees and the forcibly displaced in ways that are empirically grounded and analytically informed. The articles that follow are instructive as to how historians can challenge state-centred accounts, as they place refugees, institutions, organisations, and states in a mutually interactive framework where refugees could be seen as the driving force behind the processes of nation formation, humanitarian practices, and growing legitimacy of international institutions. By providing a range of case studies drawn from the Middle East, the volume also provides a step away from the Eurocentrism that so often defines the study of refugees, and instead shows the centrality of the developments in Europe to the Middle East and the developments in the Middle East to Europe. We, as the editors of this special issue, therefore propose the connected histories of refugeedom as the historiographical way forward in the study of refugees and the forcibly displaced. 